\title{
Quality Indicators of Chicken Broiler Raw and Cooked Meat Depending on Their Sex
}

\author{
Alena Saláková1, Eva Straková ${ }^{2}, V^{2}$ ronika Válková1, Hana Buchtová1, \\ Iva Steinhauserová ${ }^{1}$ \\ ${ }^{1}$ Department of Meat Hygiene and Technology, Faculty of Veterinary Hygiene and Ecology, University of \\ Veterinary and Pharmaceutical Sciences Brno, Czech Republic \\ ${ }^{2}$ Department of Nutrition, Husbandry and Animal Hygiene, University of Veterinary and Pharmaceutical \\ Sciences Brno, Czech Republic \\ Received January 14, 2008 \\ Accepted March 9, 2009
}

\begin{abstract}
The objective of this study was to compare the quality indicators of chicken breast meat depending on sex, to evaluate individual quality indicators and to find relationships between them. Three groups (A, B and C) of commercial meat-type hybrid broilers ROSS 308 (10 males and 10 females from each group) were used for colour measurement (CIE L*a*b*), pH, chemical analysis (amount of dry matter, fat and collagen) and texture (shear force, hardness, cohesiveness). Cooked meat indicators (texture, colour, $\mathrm{pH}$ and chemical indicators) were measured after heat treatment $\left(80^{\circ} \mathrm{C}, 30 \mathrm{~min}\right)$. In all groups we were able to prove raw meat differences between sexes only in the following indicators: carcass weight (A group $P<0.01$, B and $\mathrm{C}$ group $P<0.001$ ), breast weight (A group $P<0.01$, B and $\mathrm{C}$ group $P<0.001$ ) and $\mathrm{pH}$ value (A group $P<0.05$, B group $P<0.001$, C group $P<0.01)$. Differences were found $(P<0.05)$ between sexes in texture indicators (hardness or cohesiveness), breast meat of males was more tender. The cooked breast meat was significantly $(P<0.05)$ lighter, redder and more yellow than the raw meat. Raw meat $\mathrm{pH}$ had a significant negative correlation $(\mathrm{r}=-0.41, P<0.001)$ with raw meat lightness. Cooked meat $\mathrm{pH}$ had a significant correlation with cooked colour indicators. The amount of collagen had significant correlations with shear force $(P<0.001)$, hardness $(P<0.001)$ and cooking loss $(P<0.01)$.
\end{abstract}

Broiler breast meat, objective colour, texture, chemical composition

Increased chicken meat production and augmented interest of food-store chains to market standardized products are the reasons for making greater efforts to evaluate selected physical indicators, such as colour and tenderness of poultry meat (Abeni and Bergoglio 2001). Meat quality is defined by the combination of many factors; however, consumers attach a special importance to colour and texture. Inherent characteristics of animal, longand short-term environmental influences on animal and processing parameters that affect the carcass or meat directly are all factors that influence meat colour, texture and flavour (Lyon et al. 2004).

The colour and uniformity of poultry skin and meat and consistency of colour are important attributes according to which consumers will select poultry products for purchase and ultimately assess the final quality of the product at consumption. Producers should be concerned with factors that may negatively affect these important quality attributes (Qiao et al. 2002). Environmental condition, such as feed and housing conditions, may affect meat colour (Du and Ahn 2002). Lightness (L*) of breast muscle could be used in the technological evaluation of meat with the standardised threshold value $\mathrm{L}^{*}$, to detect pre-slaughter or processing effects, with a good reliability with different genetic strain (Abeni and Bergoglio 2001). Furthermore, a low ultimate $\mathrm{pH}$ reduces the importance of myoglobin in selectively absorbing green light, resulting in meat that appears less red and more yellow (Castellini et al. 2002). When the $\mathrm{pH}$ of meat is above the isoelectric 
point of myofibrillar proteins, water molecules are tightly bound, causing more light to be absorbed by the muscle, and meat appears darker in colour.

Texture is one of the most important attributes noted by consumers when assessing acceptability of cooked meat. Meat texture sensation is dictated by the presence of several factors including the amount of intramuscular fat, water holding capacity and actomyosin complex. However, it is the quality of collagen, which gives toughness to meat (Coró et al. 2003). Collagen is the major component of the intramuscular connective tissue and plays a key role in determining meat toughness (Liu et al. 1996). Nevertheless, chicken is commercially slaughtered at an age when collagen normally does not constitute a texture problem (Coró et al. 2003). Instrumental determination of texture, or tenderness, is usually evaluated on intact pieces or cores large enough to ensure representative sampling of muscle fibres (size and orientation) so that treatment effects can be accurately measured (Lyon and Lyon 1996).

Age and genetic strain are two inherent factors that affect meat colour and texture. Age of the animal may be important because myoglobin, the primary muscle pigment, tends to increase with age in chicken (Lyon et al. 2004). However, Smith et al. (2002) reported that the colour of broiler breast meat was not affected by age, whereas Lyon et al. (2004) reported that meat texture may be affected by age. Sandusky and Heath (1998) observed that instrumental evaluation is well correlated to sensorial estimation of poultry breast meat. Significant correlations were observed between percentage of moisture pick-up and initial $\mathrm{L}^{*}$, and raw and cooked meat $\mathrm{pH}$. At present the sex of broilers is not differentiated during their fattening.

The objective of this study is to compare the quality indicators of chicken breast meat depending on their sex of three groups of experimental samples (three successive fattening cycles), to evaluate individual quality indicators (instrumental and chemical measurements), especially the colour and texture of raw and cooked poultry breast meat, and to find relationships between those individual indicators.

\section{Materials and Methods}

Sample collection

Three groups (A, B and C from three successive fattening cycles) of commercial meat-type hybrid broilers ROSS 308 were used for quality measurements. Each group included 50 female and 50 male chickens. From the $1^{\text {st }}$ to the $40^{\text {th }}$ day of age chickens were reared separately in cages according to their sex on deep litter in an approved experimental enclosure (controlled light - photoperiod length LD $23 \mathrm{~h}$ of light and $1 \mathrm{~h}$ of dark; temperature was decreased according to the age of chickens from $31^{\circ} \mathrm{C}$ to $21^{\circ} \mathrm{C}$; and zoo-hygienic and feeding regimes) of the Department of Nutrition, Husbandry and Animal Hygiene at the Faculty of Veterinary Hygiene and Ecology, University of Veterinary and Pharmaceutical Sciences Brno. Conditions of the experiment complied with requirements for the rearing of broiler chickens described in the technological instructions for this type of broiler chicken. Feeding and watering of broilers was carried out using plastic tube feeders and hanging drinkers. All broiler chickens were fed ad libitum a commercial complete mixture (based on vegetable components with mentioned divergences in diet) used for meat-type broiler chickens (starter - day 1 to day 14, grower - day 15 to day 28 and finisher - day 29 to day 40). The main compositions of the final diet are shown in Table 1. Ten males and ten females were taken from each group to evaluate the quality indicators. The birds were deboned after chilling on the same day that they were slaughtered (approximately $4 \mathrm{~h}$ post mortem). Breast meat (musculus pectoralis major) was stored for $24 \mathrm{~h}$ at the temperature of $4{ }^{\circ} \mathrm{C}$. Colour, $\mathrm{pH}$ and chemical indicators were measured on raw and cooked breast meat; cooked meat was used for the texture measurement.

Table 1. The main compositions of final diet

\begin{tabular}{|l|c|c|c|}
\hline Composition & A & B & C \\
\hline Crude protein $(\mathrm{N} \times 6.25)\left[\mathrm{g} \cdot \mathrm{kg}^{-1}\right]$ & 226.0 & 201.4 & 187.9 \\
\hline Fat $\left[\mathrm{g} \cdot \mathrm{kg}^{-1}\right]$ & 68.6 & 79.4 & 70.8 \\
\hline Fibre $\left[\mathrm{g} \cdot \mathrm{kg}^{-1}\right]$ & 17.6 & 16.9 & 22.2 \\
\hline Ash $\left[\mathrm{g} \cdot \mathrm{kg}^{-1}\right]$ & 52.8 & 46.5 & 52.0 \\
\hline Metabolizable energy $\left[\mathrm{MJ} \cdot \mathrm{kg}^{-1}\right]$ & 12.5 & 13.2 & 12.3 \\
\hline
\end{tabular}


The indicators of cooked breast meat were measured after heat treatment. Breast meat was heat-treated in plastic bags separately in a water bath $\left(82^{\circ} \mathrm{C}\right)$, the core temperature of samples was kept at $80{ }^{\circ} \mathrm{C}$ for $30 \mathrm{~min}$. Samples were cooled at room temperature and stored overnight at $4 \pm 2{ }^{\circ} \mathrm{C}$ (Coró et al. 2003).

Instrumental measurement of colour

The surface colour of raw and cooked meat was measured by the CIE L*a*b* system using Minolta CM 2600d (Konica Minolta, Japan). Measuring area of $8 \mathrm{~mm}$, illuminant D65 and $10^{\circ}$ standard observer were used. The instrument was standardized using a standard white plate. CIE L* - lightness, $\mathrm{a}^{*}$ - redness, $\mathrm{b}^{*}$ - yellowness, Chroma $\mathrm{C}^{*}=\left(\mathrm{a}^{* 2}+\mathrm{b}^{* 2}\right)^{0.5}$ and hue $\mathrm{h}^{\circ}=\tan ^{-1}\left(\mathrm{~b}^{*} / \mathrm{a}^{*}\right)$ were calculated using available software (Spectra Magic 3.61). The result stated for each sample is the mean value $\pm \mathrm{S}$. D. of ten measurements.

Instrumental measurement of texture

Cooked samples were tested by Texture Profile Analysis (TPA) and by the Warner-Bratzler test using the Instron Universal Testing Machine (model 5544) (Instron Corporation, England). Indicators were obtained using available computer software (Merlin, Series IX).

For TPA cylinder samples $(1 \mathrm{~cm}$ high, $1.25 \mathrm{~cm}$ in diameter) were compressed twice to $50 \%$ of their original height with a compression platen of $36 \mathrm{~mm}$ in diameter. Force time curves were recorded at a crosshead speed of $50 \mathrm{~mm} / \mathrm{min}$. Hardness $(\mathrm{N})$ - the peak force required for the first compression and cohesiveness - ratio of the positive force area during the second compression to that in the first compression were evaluated (Szczesniak 2002).

The shear force $(\mathrm{N})$ was measured on samples $(2.0 \mathrm{~cm}$ wide, $1.0 \mathrm{~cm}$ long and $1.5 \mathrm{~cm}$ high) using the WarnerBratzler test. Crosshead speed was set to $80 \mathrm{~mm} / \mathrm{min}$.

The result stated for each sample is the mean value $\pm \mathrm{S}$. D. of six measurements.

Chemical indicators

The meat samples $(100 \mathrm{~g})$ were homogenized. The following indicators were subsequently determined: amount of dry matter (sea-sand drying, $24 \mathrm{~h}$ at $103 \pm 2{ }^{\circ} \mathrm{C}$, CSN ISO 576021 ) and fat (analysed on the SOXTEC instrument made by TECATOR, with diethylether as the extraction agent). The content of collagen was computed from the content of the amino acid hydroxyproline (recalculating coefficient $f=8$ ). Hydroxyproline was determined quantitatively by photometric measurement of absorbance at $550 \mathrm{~nm}$ on a UV/VIS spectrophotometer Neo 1000 (England). Chemical indicators were measured in raw and cooked meat.

Cooking loss, $\mathrm{pH}$ value

Cooking loss was analysed as [sample weight before cooking minus sample weight after cooking] $\times 100 /$ sample weight before cooking.

Ultimate $\mathrm{pH}$ (24 h after slaughter) and $\mathrm{pH}$ of cooked meat were measured with a needle probe SenTix Sp on pH-meter 340i WTW (WTW, Germany).

Data analysis

Statistical data analyses were conducted using the statistical program STATISTICA 7 CZ (StatSoft, Czech Republic). The data were subjected to correlation analysis to determine possible relationships between them. Student's $t$-test was applied for determination of differences between males and females and between the control and experimental group of samples. The $0.05,0.01$ and 0.001 levels of significance were used.

\section{Results and Discussion}

Raw breast meat chemical composition, $\mathrm{pH}$ and colour are presented in Table 2. The chemical composition ranged from $25.42 \%$ to $26.69 \%$ for dry matter, $0.60 \%$ to $3.28 \%$ for fat and $0.30 \%$ to $0.62 \%$ for collagen. Colour characteristics ranged from 52.24 to 59.43 for $\mathrm{L}^{*},-1.39$ to -0.18 for $\mathrm{a}^{*}, 4.02$ to 6.58 for $\mathrm{b}^{*}$. $\mathrm{pH}$ values ranged from 5.66 to 6.08 . $\mathrm{pH}$ values showed differences $(P<0.05)$ between males and females in each group of samples.

Significant differences were found between males and females in the indicators of carcass weight and breast weight in all the three groups of experimental samples. If the main criterion during fattening of males was the carcass weight indicator, it would be more expedient to fatten only males.

In group $\mathrm{A}$, no differences were found $(P<0.05)$ between males and females in dry matter, collagen and fat contents. Differences were found between males and females in colour indicators $\mathrm{L}^{*}(P<0.01), \mathrm{b}^{*}(P<0.001)$ and $\mathrm{C}^{*}(P<0.001)$. The meat of females was significantly lighter, more yellow, and of lower $\mathrm{pH}$. Higher muscle $\mathrm{pH}$ is associated with darker meat than that of lower $\mathrm{pH}$ (Fletcher 1999). In group B, a difference was found $(P<0.05)$ between males and females only in the collagen content. Differences were not found between males and females in the colour indicator. In group $\mathrm{C}$, differences 


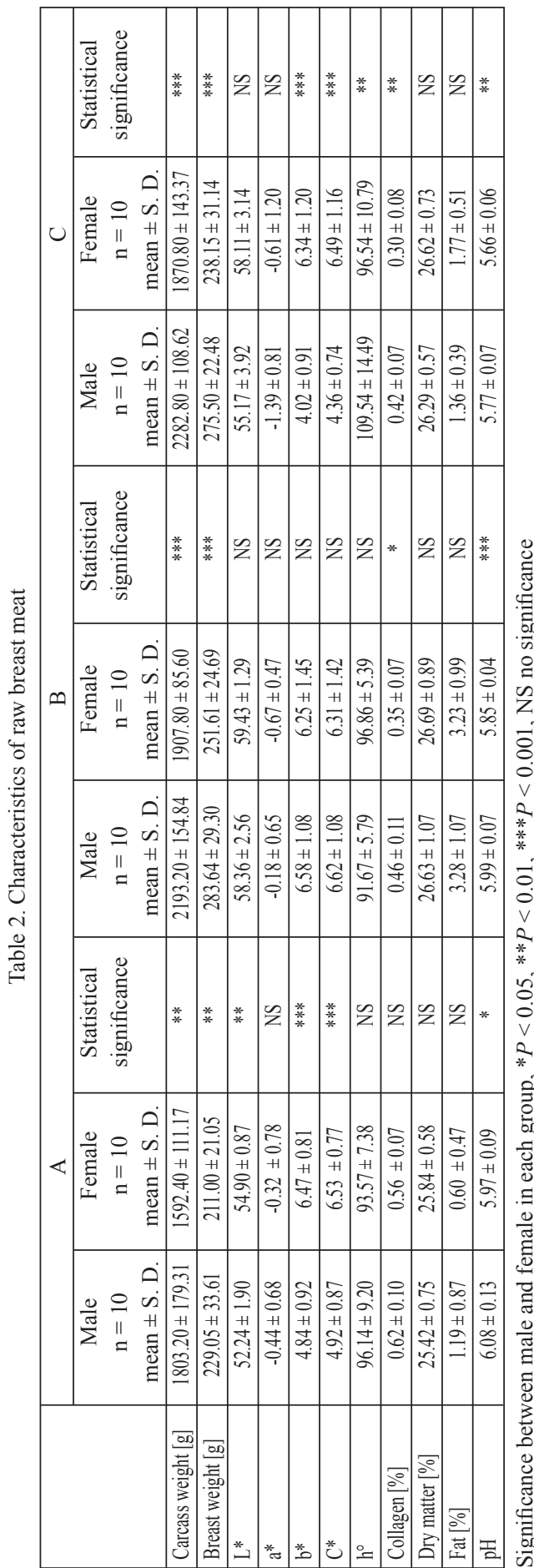

were found between males and females in colour indicators $\mathrm{b}^{*}(P<0.001), \mathrm{C}^{*}$ $(P<0.001)$ and $\mathrm{h}^{\circ}(P<0.01)$ and in the collagen content $(P<0.01)$. The meat of females was significantly more yellow.

Cooked breast meat colour indicators, texture characteristics and chemical composition are presented in Table 3 . Colour ranged from 79.39 to 82.48 for $\mathrm{L}^{*}, 1.97$ to 2.72 for $\mathrm{a}^{*}$ and 14.28 to 15.85 for $b^{*}$. Texture indicators ranged from $32.80 \mathrm{~N}$ to $57.45 \mathrm{~N}$ for shear forces, $21.62 \mathrm{~N}$ to $37.14 \mathrm{~N}$ for hardness, and 1.21 to 1.23 for cohesiveness. In cooked meat, the amount of collagen was in range $0.54 \%$ to $0.83 \%$, dry matter in $32.40 \%$ to $35.82 \%$ and fat in $1.64 \%$ to $2.93 \%$. Therefore it was obvious that the chemical content of meat in the individual broiler groups was balanced. Texture characteristics varied a bit, the biggest differences were in the shear force indicator, and as for the colour characteristics, lightness $\left(\mathrm{L}^{*}\right)$ showed the biggest variance of values.

In group $\mathrm{A}$, difference was found $(P<0.05)$ between males and females in the indicator of shear force and hardness. Meat of males was more tender. In group $\mathrm{B}$, differences were found between males and females in hardness $(P<0.05)$, cooked collagen $(P<0.01)$, cooked fat $(P<0.05)$, cooked a* $(P<0.05)$, cooked $\mathrm{h}^{\circ}(P<0.05)$ and cooking loss $(P<0.05)$. Meat of males from group $B$ was more tender, contained more collagen and fat, its colour was redder, and it showed higher cooking losses. In group $\mathrm{C}$ of samples, a difference was found $(P<0.01)$ between males and females only in cohesiveness.

Qiao et al. (2001) separated breast fillets into three groups according to meat lightness $\left(\mathrm{L}^{*}\right)$ as follows: lighter than normal (light, $\mathrm{L}^{*}>53$ ), normal $\left(48<\mathrm{L}^{*}<53\right)$, and darker than normal (dark, $\mathrm{L}^{*}<46$ ). According to the $\mathrm{L}^{*}$ value, samples from the group A can be classified as normal and the other two groups of experimental samples can be classified into the group lighter than normal.

Group A showed significant differences 


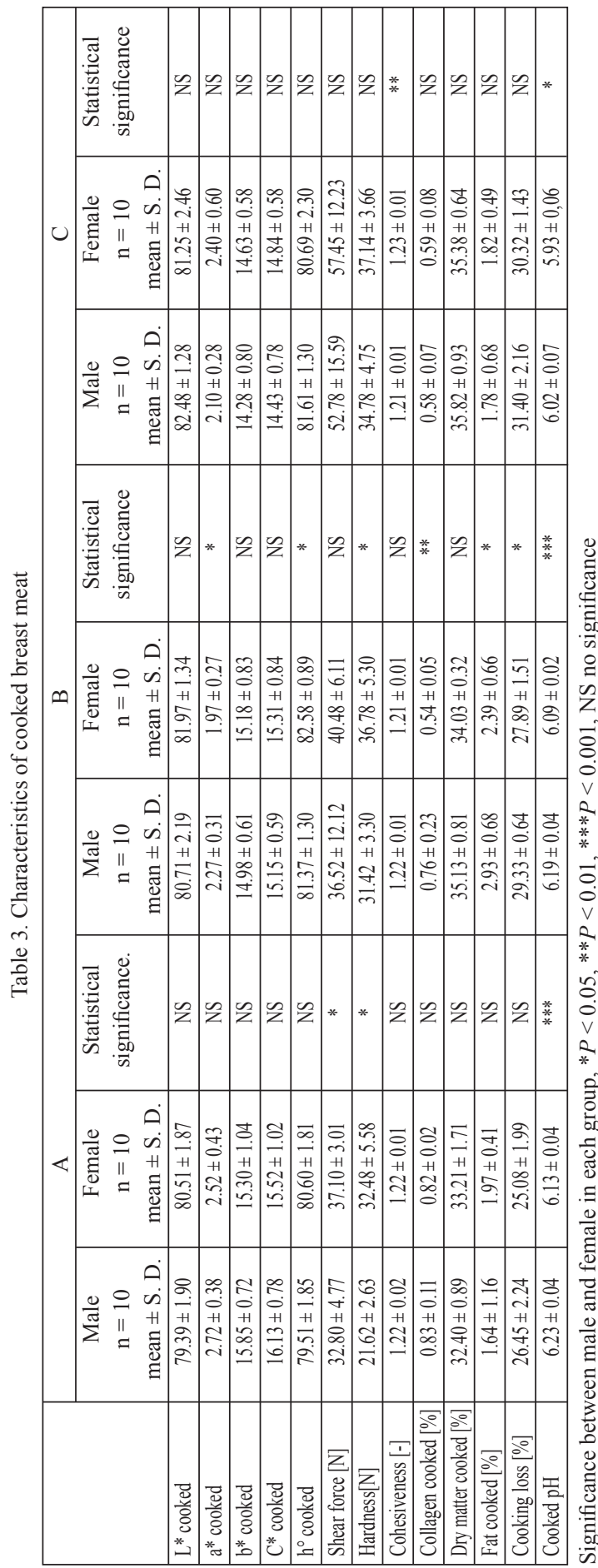

$(P<0.05)$ compared to group B in the following indicators: hardness, cooking loss, $\mathrm{pH}, \mathrm{L}^{*}$ and $\mathrm{L}^{*}$ cooked and $\mathrm{a}^{*}$ cooked. Furthermore, group A showed a significant difference $(P<0.05)$ in the content of dry matter and collagen for both the raw breast and cooked breast compared to group B. Compared to group C, group $\mathrm{B}$ had significantly higher $(P<0.05)$ content of fat, we also found differences in content of shear force, cooking loss, $\mathrm{pH}$ and colour indicator $\left(\mathrm{L}^{*}, \mathrm{~b}^{*}, \mathrm{C}^{*}, \mathrm{~h}^{\circ}\right.$ and $b^{*}$ cooked). Group A showed significant differences $(P<0.05)$ compared to group $\mathrm{C}$ in the shear force, hardness, cooking loss, $\mathrm{pH}$, $\mathrm{L}^{*}$, cooked colour indicators and in chemical indicators. Pearson correlation coefficients are presented in Tables 4, 5 and 6. According to Fletcher (1999), muscle $\mathrm{pH}$ and meat colour are highly correlated. Several researchers demonstrated that significant negative correlations exist between breast meat lightness colour values and breast meat $\mathrm{pH}$ (Barbut 1993; Fletcher 1995; Allen et al. 1997).

Raw meat $\mathrm{pH}$ had significant negative correlation with lightness (Table 4). We also found correlations between indicators of raw meat. Lightness $\left(\mathrm{L}^{*}\right)$ and yellowness $\left(\mathrm{b}^{*}\right)$ were found to correlate negatively to $\mathrm{pH}$, whereas redness $\left(\mathrm{a}^{*}\right)$ had a positive correlation. In our study we found a relationship between colour and $\mathrm{pH}$. When the $\mathrm{pH}$ value was higher, meat was darker, less yellow and redder. Thus as the $\mathrm{pH}$ increased, the values of lightness and yellowness decreased but that of redness increased (Allen et al. 1997).

Raw meat colour value $L^{*}$ resulted in significant positive correlation with cooked meat L* value (Table 5) and significant negative correlation with $\mathrm{pH}$ of cooked meat. Fletcher 
Table 4. Multivariate correlation coefficient between colour and $\mathrm{pH}$ of raw breast meat

\begin{tabular}{|c|c|c|c|c|c|c|}
\hline & $\mathrm{L} *$ & $\mathrm{a} *$ & $\mathrm{~b}^{*}$ & $\mathrm{C}^{*}$ & $\mathrm{~h}^{\circ}$ & $\mathrm{pH}$ \\
\hline $\mathrm{L}^{*}$ & - & -0.06 & $0.45^{* * *}$ & $0.49 * * *$ & 0.06 & $-0.41 * * *$ \\
\hline $\mathrm{a}^{*}$ & -0.06 & - & $0.49 * * *$ & $0.44 * * *$ & $-0.94 * * *$ & 0.23 \\
\hline $\mathrm{b}^{*}$ & $0.45^{* * *}$ & $0.49 * * *$ & - & $0.99 * * *$ & $-0.60 * * *$ & -0.05 \\
\hline $\mathrm{C}^{*}$ & $0.49 * * *$ & $0.44 * * *$ & $0.99 * * *$ & - & $-0.53 * * *$ & -0.09 \\
\hline $\mathrm{h}^{\circ}$ & 0.06 & $-0.94 * * *$ & $-0.60 * * *$ & $-0.53 * * *$ & - & -0.22 \\
\hline $\mathrm{pH}$ & $-0.41 * * *$ & 0.23 & -0.05 & -0.09 & -0.22 & - \\
\hline
\end{tabular}

$* P<0.05, * * P<0.01, * * * P<0.001$

Table 5. Multivariate correlation coefficients between colour of cooked breast meat and raw breast meat

\begin{tabular}{|l|c|c|c|c|c|c|}
\hline & $\mathrm{L}^{*}$ & $\mathrm{a}$ & $\mathrm{b}$ & $\mathrm{C}^{*}$ & $\mathrm{~h}^{\circ}$ & $\mathrm{pH}$ \\
\hline $\mathrm{L} *$ cooked & $0.43^{* * *}$ & $-0.35^{* *}$ & -0.07 & -0.03 & $0.37^{* *}$ & $-0.31^{*}$ \\
\hline $\mathrm{a}^{*}$ cooked & -0.08 & 0.12 & 0.08 & 0.08 & -0.12 & 0.16 \\
\hline $\mathrm{b}$ cooked & -0.25 & 0.15 & 0.10 & 0.07 & -0.21 & $0.45^{* * *}$ \\
\hline $\mathrm{C}^{*}$ cooked & $-0.28^{*}$ & 0.18 & 0.10 & 0.06 & -0.23 & $0.47^{* * *}$ \\
\hline $\mathrm{h}^{\circ}$ cooked & $0.38^{* *}$ & -0.25 & 0.28 & 0.04 & -0.19 & 0.09 \\
\hline $\mathrm{pH}$ cooked & $-0.46^{* * *}$ & $0.26^{*}$ & $-0.16^{*}$ & -0.10 & -0.25 & $0.65^{* *}$ \\
\hline
\end{tabular}

$* P<0.05, * * P<0.01, * * * P<0.001$

et al. (2000) reported that raw meat colour values resulted in highly significant positive correlations with all of the corresponding cooked meat colour values.

Raw meat chemical characteristics resulted in significant positive correlation with all the corresponding cooked meat chemical characteristics (collagen $r=0.62$, dry matter $r=0.34$, and fat $\mathrm{r}=0.35$ ).

We found out that the dry matter content correlated significantly with $\mathrm{L}^{*}(\mathrm{r}=0.40)$ and $\mathrm{pH}(\mathrm{r}=-0.39)$. It corresponded to Allen et al. (1998), who reported significant correlations between percentage of moisture pick-up and initial $\mathrm{L}^{*}$, and raw and cooked meat $\mathrm{pH}$. $\mathrm{L}^{*}$ value correlated positively $(\mathrm{r}=0.36)$ with cooking loss. Barbut (1993) and Allen et al. (1998) also reported that $\mathrm{L}^{*}$ value of poultry breast positively correlated with cooking loss.

Table 6 shows correlation coefficients between chemical indicators and texture indicators. The amount of collagen had significant correlations with shear force $(P<0.001)$, hardness $(P<0.001)$ and cooking loss $(P<0.01)$, but no significant correlations were found with collagen in cooked meat. Coró et al. (2003) found that shear force value was not related to the amount of collagen.

Table 6. Multivariate statistics between chemical indicators and texture indicators

\begin{tabular}{|l|c|c|c|c|c|c|}
\hline & Collagen & Dry matter & Fat & $\begin{array}{c}\text { Collagen } \\
\text { cooked }\end{array}$ & $\begin{array}{c}\text { Dry matter } \\
\text { cooked }\end{array}$ & Fat cooked \\
\hline Shear force & $-0.47 * * *$ & $0.31^{*}$ & 0.06 & -0.19 & $0.50 * * *$ & -0.05 \\
\hline Hardness & $-0.52 * * *$ & $0.32 *$ & 0.19 & $-0.38 * *$ & $0.54 * * *$ & 0.06 \\
\hline Cohesiveness & -0.25 & 0.11 & 0.09 & -0.04 & -0.05 & -0.09 \\
\hline Cooking loss & $-0.39 * *$ & 0.09 & 0.08 & $-0.32 *$ & $0.77 * * *$ & 0.15 \\
\hline
\end{tabular}

$* P<0.05, * * P<0.01, * * * P<0.001$

In all groups, raw meat differences between sexes were found only in the following indicators: carcass weight, breast weight and $\mathrm{pH}$. If the main criterion during broiler fattening was the carcass weight indicator, it would be more expedient to fatten only males. The common feature of all the groups was that there was no difference between males 
and females regarding the content of dry matter and fat. In the case of cooked meat the difference between sexes was minimal; breast meat of males was more tender.

The $\mathrm{pH}$ of raw meat had a strong impact on the colour of cooked meat. Raw meat $\mathrm{pH}$ had significant negative correlation with raw meat lightness. Cooked meat $\mathrm{pH}$ had significant correlation with cooked colour indicators. $L^{*}$ of cooked meat can be deduced from $\mathrm{L}^{*}$ of raw meat. Cooked meat was significantly $(P<0.05)$ lighter, redder and more yellow than raw meat. The amount of collagen had significant correlations with shear force, hardness and cooking loss.

\section{Jakostní ukazatele syrového a tepelně opracovaného masa kuřecích brojlerů v závislosti na pohlaví}

Cílem práce bylo srovnání jakostních ukazatelů prsní svaloviny kưrecích brojlerů v závislosti na jejich pohlaví, zhodnotit jednotlivé ukazatele a najít vztahy mezi nimi. Prsní svalovina pocházející ze tří skupin (A, B a C) komerčně chovaných brojlerů ROSS 308 (10 kohoutků a 10 slepiček z každé skupiny) byla použita pro měření barvy (CIE L*a*b*), $\mathrm{pH}$, stanovení chemických indikátorů (obsah vody, tuku a kolagenu) a instrumentální hodnocení textury (střižní síla, tvrdost, soudržnost). Indikátory tepelně opracovaného masa (textura, barva, $\mathrm{pH}$ a stanovení chemických parametrů) byly měřeny po tepelném opracování $\left(80^{\circ} \mathrm{C}, 30 \mathrm{~min}\right)$. Ve všech skupinách byl prokázán rozdíl mezi pohlavími v hmotnostech jatečně upraveného těla (A skupina $P<0.01$, B a $\mathrm{C}$ skupina $(P<0.001)$, hmotnostech prsní svaloviny (A skupina $P<0.01, \mathrm{~B}$ a $\mathrm{C}$ skupina $P<0.001$ ) a hodnotách $\mathrm{pH}$ (A skupina $P<0.05$, B skupina $P<0.001$, C skupina $P<0.01$ ). Mezi pohlavími byly zjištěny významné rozdíly $(P<0.05)$ v textuře. Maso kohoutků je křehčí v porovnání se slepičkami. Tepelně opracované maso bylo významně světlejší a mělo vyšší hodnoty ukazatelů $a^{*} a b^{*}$ než čerstvé maso. $\mathrm{pH}$ masa vykazovalo negativní korelace $(\mathrm{r}=-0.41, P<0.001)$ se světlostí syrového masa. pH tepelně opracovaného masa vykazovalo signifikantní korelace $\mathrm{s}$ barevnými indikátory tepelně opracovaného masa. Obsah kolagenu významně koreluje s hodnotou střižní síly $(P<0.001)$, tvrdostí $(P<0.001)$ a ztrátami hmotnosti př̀i tepelném opracování $(P<0.01)$.

\section{Acknowledgement}

This research was supported by the Ministry of Education, Youth and Sports of the Czech Republic, Grant No. MSM6215712402 Veterinary Aspects of Food Safety and Quality.

\section{References}

Abeni F, Bergoglio G 2001: Characterization of different strains of broiler chicken by carcass measurements, chemical and physical parameters and NIRS on breast muscle. Meat Sci 57: 133-137

Allen CD, Fletcher DL, Northcutt JK, Russell SM 1998: The relationship of broiler breast color to meat quality and shelf-live. Poultry Sci 77: 361-366

Allen CD, Russell SM, Fletcher, DL 1997: The relationship of broiler breast meat color and $\mathrm{pH}$ to shelf life and odor development. Poultry Sci 76: 1042-1046

Barbut S 1993: Colour measurement for evaluating the pale soft exudative (PSE) occurrence in turkey meat. Food Res Int 26: 39-43

Castellini C, Mungai C, Dal Bosco 2002: A Effect of organic production system on broiler carcass and meat quality. Meat Sci 60: 219-225

Coró FAG, Youssef EY, Shimokomaki M 2003: Age related changes in poultry breast meat collagen pyridinoline and texture. J Food Biochem 26: 533-541

Du M, Ahn DU 2002: Effect of dietary conjugated linoletic acid on the growth rate of live birds and on the abdominal fat content and quality of broiler meat. Poultry Sci 81: 428-433

Fletcher DL 1995: Relationship of breast meat color variation to muscle pH and texture. Poultry Sci 74S: 120

Fletcher DL 1999: Broiler breast meat color variation, pH and texture. Poultry Sci 78: 1323-1327

Fletcher DL, Qiao M, Smith DP 2000: The relationship of broiler breast meat color and pH to cooked meat colour and $\mathrm{pH}$. Poultry Sci 79: 784-788

Liu A, Nishimura T, Takahashi K 1996: Relationship between structural properties of intramuscular connective tissue and toughness of various chicken skeletal muscles. Meat Sci 43: 43-49 
Lyon BG, Lyon CE 1996: Texture evaluation of cooked, diced broiler breast samples by sensory and mechanical methods. Poultry Sci 75: 812-819

Lyon BG, Smith DP, Lyon CE, Savage EM 2004: Effect of diet and feed withdrawal on sensory descriptive and instrumental profiles of broiler breast fillets. Poultry Sci 83: 275-281

Qiao M, Fletcher DL, Smith DP, Northcutt JK 2001: The effect of broiler breast meat color on pH, moisture, water holding capacity, and emulsification capacity. Poultry Sci 80: 676-680

Qiao M, Fletcher DL, Northcutt JK, Smith DP 2002: The relationship between raw broiler breast meat colour and composition. Poultry Sci 81: 422-427

Sandusky CL, Heath JL 1998: Sensory and instrument-measured ground chicken meat color. Poultry Sci 77: 481-486

Smith DP, Lyon CE, Lyon BG 2002: The effect of age, dietary carbohydrate sours and feed withdrawal on broiler breast color. Poultry Sci 81: 1584-1588

Szczesniak AS 2002: Texture is sensory property. Food Qual Prefer 13: 215-225 